\title{
DEVELOPMENT AND DISTRIBUTION OF INNOVATION FORMS OF SOCIAL CAPITAL ACCUMULATION IN UKRAINE
}

\author{
Nafus I., \\ Ukraine, Chernivtsi, Yuriy Fedkovich National University of Chernivtsi \\ PhD student of the Department of Economic Theory, \\ management and administration
}

DOI: https://doi.org/10.31435/rsglobal_ijite/30122019/6848

\section{ARTICLE INFO \\ Received 17 October 2019 \\ Accepted 14 December 2019 \\ Published 30 December 2019}

\section{KEYWORDS}

social capital; accumulation of social capital; social entrepreneurship; Internet networks; digitization; egovernment.

\begin{abstract}
In the article author defines the essence of social capital and basic theoretical approaches to its understanding. The possibility of diversification and dissemination of innovative forms of social capital accumulation in Ukraine have been proved. It is shown that new forms of manifestation and realization of social capital are emerging, which create new opportunities for socialization of economic relations and formation of new public institutions, which can reverse the development of the economy and the accumulation of social capital. It describes such new forms of social capital as: social entrepreneurship, social Internet networks, freelancing, sharing economy, digitization of economic entities interaction, crowdfunding, crowdsourcing, crowdsourcing, e-government, creation of "digital" communities, specially designed programs and projects, the task of which is to stimulate the activity of citizens and regulate their participation in solving local issues, the formation of corporate social capital, the creation of special social institutions at the global level.
\end{abstract}

Citation: Nafus I. (2019) Development and Distribution of Innovation Forms of Social Capital Accumulation in Ukraine. International Journal of Innovative Technologies in Economy. 7(27). doi: 10.31435/rsglobal_ijite/30122019/6848

Copyright: (C) 2019 Nafus I. This is an open-access article distributed under the terms of the Creative Commons Attribution License (CC BY). The use, distribution or reproduction in other forums is permitted, provided the original author(s) or licensor are credited and that the original publication in this journal is cited, in accordance with accepted academic practice. No use, distribution or reproduction is permitted which does not comply with these terms.

Introduction. With the development of socio-economic relations under the influence of internal and external factors is the development and formation new of social capital forms. This is an objective tendency of socialization of the economy, concerning the spread and diversification of various forms of social capital accumulation at each of the levels of management, and is an important factor of economic growth.

Social capital is nowadays regarded as an additional resource that provides for relations between people and allows for the reconciliation of socio-economic contradictions [5].

In explaining the essence of social capital, representatives of different social and behavioural sciences use the following basic approaches to study the essence of social capital:

1. Socio-anthropological (F. Fukuyama, 2004), according to which social capital means the natural desire of people for association and communication (benevolence, friendship, social relations), is the biological basis of the social order [14].

2. Sociological (J. Coleman, 2001; R. Rose, 2002), according to which social capital is the norms, networks and organizations through which individuals benefit. [11].

3. Economic-institutional (R. Patnem, 2000), whose representatives claim that individuals use social capital resources in their relationships to maximize individual utility [9].

4. Political science (Glaester, 2001), according to which the treatment of social capital is defined as relations and norms that shape the quantity and quality of social interactions in society, and social unity is defined as the most important factor for economic prosperity and sustainable development [2]. 
In modern conditions, although the main components of social capital remain unchanged, their forms of manifestation and realization are emerging, which create new opportunities for socialization of economic relations and the formation of new public institutions that can reverse the economic development and accumulation of social capital.

Results of the research. The main areas of diversification and dissemination of innovative forms of social capital accumulation should be considered by the following criteria:

1) by types of social innovations at different levels of functioning of the economy;

2) by sources of formation and socio-economic consequences;

3) the possibility of influencing the development of economic relations and the improvement of public institutions.

Social innovations as a source of social capital have a focus on meeting certain social goals, needs, interests of different economic entities that have not been satisfied; changing the relationships between individuals and social groups and governance mechanisms; the search for more effective public institutions capable of promoting the sustainable development of society and the economy. They must ensure the communicative integrity of the social system, the growth of social capital as a resource of trust in society.

At different levels of economic relations functioning, social innovations have different forms, scales and influence on the formation of social capital. An important role in the formation of social capital at the nanoscale is the individual's social responsibility - for his or her well-being and the wellbeing of the family, for maintaining relationships with groups, partners, business, networks and more. Recently, the accumulation of social capital at the nanoscale is due to the development of social entrepreneurship. According to the survey "Best Experience and Modern Trends in the Development of Social Entrepreneurship: Ukraine", the following features of the development of social entrepreneurship in Ukraine appeared: the most common organizational form of social entrepreneurship is individuals (29.1\%) and public organizations (25.4\%); the most common type of social enterprise is SELI - "social enterprises of labour integration" (54.5\%); by duration of operation, most social enterprises belong to groups of $1-3$ years $(38.2 \%)$ and 10 years and more $(21.8 \%)$; the majority of enterprises have up to five employees (45.4\%); The mission of most social enterprises is related to the social sphere: improving the quality of life of vulnerable populations, developing local communities and promoting healthy lifestyles; a third of enterprises have an environmental mission; most social enterprises have an annual financial turnover of up to UAH 500 000. $(67.3 \%, 2015)$ [4].

Social entrepreneurship is not always properly perceived as social capital, though it is an effective form of accumulation. The study also identified the key difficulties that social enterprises face in the course of doing business: the indifference of society to the activities of social enterprises; limited information about social enterprises; difficulties in obtaining financing, high administrative costs and rent [12].

A relatively new social phenomenon that contributes to the accumulation of social capital has become social Internet networks. Networks can be professional in nature, and in this sense they are a source of economic capital for network members. Social networks are characterized by openness, which allows to expand the network of contacts, to receive additional information, to consult, to transfer / share approaches to solving professional tasks. Modern Internet technologies and the availability of social networks contribute to the spread of new forms of employment and professional communication, an increase in social contacts with colleagues, specialists-allies, which is a source of UK for individual professionals. The most common freelance professions are programmers; site designers, copywriters, specialists in the promotion, production, development and refinement of sites; translators; experts in 3D-modeling, etc. Setting up professional networks occurs through freelance exchanges (through which about $70 \%$ of freelancers find work), as well as through social networks (LinkedIn, Facebook, etc.). The most popular in Ukraine are the following freelance services: Upwork.com, Kabanchik.ua, Freelancehunt.com and Freelance.ua.

Ukraine is one of the leaders in freelancing. According to special studies, in 2013-2017, Ukraine ranked first in Europe and fourth in the world in terms of employment on digital platforms. While in 2011 the number of freelancers in Ukraine was approximately 9 thousand people, in 2016 it was already 60 thousand. In 2017, it was found that Ukrainian freelancers are relatively young and have a high level of education. According to the survey, 55\% of respondents have a college degree and $2 \%$ have a $\mathrm{PhD} .25 \%$ of respondents believe that working through digital platforms is their main 
source of income. $33.8 \%$ of the respondents work for a Ukrainian customer, while others - wholly or partly for foreign clients [13].

The digitalization of society and the economy contributes to changing ways of communication between people. The digital society uses modern digital technologies for self-realization of personality, change of place of work, organization of rest, distance learning, and also for interaction with other citizens in the course of achievement of economic, social and public goals.

Modern digital technologies (Internet of things, robotics and cyber systems, artificial intelligence, big data, paperless technologies, 3D printing, cloud and fog computing, unmanned and mobile technologies, biometric, quantum technologies, identification technologies, blockchain, etc.) share their benefits by getting the information they need or by using available cloud services that allow you to migrate computing resources and data to remote Internet servers.

Digitalization has enabled small businesses and project teams to grow quickly and efficiently through start-ups, enabling them to quickly communicate and reach global levels. The rapid development of digital technologies is accompanied by innovations in social relations. If the years 2010-2020 were characterized by the proliferation of social networks and messengers, the next stage involves the construction of a so-called neuronet, that is, a network where communication between humans, animals and things will be based on the principles of neuro-communication, the use of artificial intelligence and the Comprehensive Internet of people, things, data, data etc.

A new phenomenon is the emergence of business models of sharing economy, which works on the basis of digital technologies (shared living, use of cars, offices, gadgets, even, cloud technologies). Sharing economics is based on the use of social networks and online sites as a means of communication. The main principles of its existence are: self-regulation (equal responsibility of all participants for all possible consequences); environmental friendliness of the solutions (keeping the activity safe and environment friendly); rationality (all participants have complete information, and their actions are aimed at maximizing the benefits to both parties); openness (total information openness and barrier-free transparency); "Evangelism" (understanding the benefits of goods or services by users of goods and services, but also realizing benefits for society that matter more than commercial profit) [15].

A significant influence on the socialization of economic relations and the formation of social capital is exercised by E-government - a model of public administration, based on the use of modern information and communication technologies, which allows to improve the interaction of citizens with state bodies. Today, $95 \%$ of all interactions with the state do not require the participation of people, the processes take place automatically, unnoticed by citizens, in particular through the electronic office, you can see all your income, expenses, bank account status, you can make a request to state bodies with an electronic signature and get prompt answer, form a tax return, sign contracts, vote, participate in referendums and more.

Modern digital technologies (Internet platforms) allow to form new tools of mutually beneficial interaction between private investors and developers of certain projects. An example is crowdfunding as an innovative tool that allows you to raise money for the implementation of digital economy ideas and projects through a large number of people. "For developers, the benefits of using this type of financing are the low cost of capital, access to a lot of information. For individual investors, it is more open and accessible to understand and use than other traditional financing options; the opportunity to invest small sums in absolutely any project, and therefore the small risks; access to a new product before its official launch; participation in the "community", the opportunity to exchange ideas, ideas, as well as being part of innovative projects; support for creative ideas and projects" [6, p. 147].

Another form of crowdsourcing is the method of online lending to individuals by other individuals or companies through specially created online resources. These are the so-called P2P loans. In 2016, the P2P lending segment accounted for almost $70 \%$ of the world market and is projected to decline to $54 \%$ by 2021 , showing a nearly $16 \%$ decline in market share [3]. The most popular crowdfunding platforms in Ukraine are the Ukrainian Philanthropic Stock Exchange, "Commonwealth", Na-Starte, KUB and GoF, whose activities are mainly focused on humanitarian, social, environmental, cultural, educational projects. The first in Ukraine was established in 2011. The Ukrainian Charity Exchange is an independent nationwide social infrastructure for online charity. Over 7 years of existence of this stock exchange, UAH 159 million was raised. Only for charity. Community-Based was founded in 2012 and focuses primarily on innovative, cultural projects that are 
not aimed at generating financial benefits. As of 01.03.2019, this platform has raised funds for the amount of UAH 20.2 million. [8].

If crowdfunding raises funds, then another form - crowdsourcing - allows a concerted effort to do a specific job. In 2019, the WikiInvestigation team unveiled a crowdsourcing investigation platform that allows them to jointly investigate corruption. Crowdfunding and crowdsourcing are networking methods that are based on a high level of trust, indifference, voluntariness, initiative of the participants, united for the common purpose. The development of such a network allows differently to form organizational structures, to distribute work and to increase its efficiency.

Networks establish a horizontal communication system, improve the degree of selforganization (in the absence of rigid organizational structures), and ensure the dominance of collective interest over the private.

Networking is the first, most dynamic mechanism for the accumulation of modern forms of social capital.

The second mechanism should be explained on the basis of the idea of increasing public trust. It should be based on the formation of new approaches to the structure of social organization, a certain social order.

The problem lies in the inefficiency of public institutions, their inability to unite society and direct it to achieve common goals on the principles of mutual trust, tolerance, and coherence of economic interests. Ukrainian society seeks to create new frames of social interaction, new types of social contacts. In particular, that is why voters of President V. Zelensky believe that his victory in the elections is connected with their desire for a radical renewal of power $(69 \%)$. The main motives for voting for parties in the parliamentary elections were: new ideas and proposals (25\%), leaders (29\%), the desire to support the newly elected president (14\%), the desire for renewal (11\%). In carrying out the reforms, citizens rely on the newly elected President Vladimir Zelensky (66\%), the newly elected Verkhovna Rada (43\%) and the future government (35.5\%). All other instances previously relied on by citizens for reform have significantly lost their value - NGOs, Western countries, the IMF, and the World Bank, scientists. In 2019, compared to 2017, Ukrainians became more satisfied with their level of personal freedom, their ability to influence their own lives and society. In particular, the level of satisfaction with public participation opportunities increased from 3.2 to 3.7 points (this aspect was satisfied by $32 \%$ in $2017,44 \%$ in 2019 , not satisfied $-22 \%$ in $2017,13 \%$ in 2019 ), the ability to be independent - from 3.5 to 3.8 points (satisfied with $45 \%$ in 2017, 58\% in 2019, not satisfied - $17 \%$ in $2017,13 \%$ in 2019), the ability to influence what is happening with them - from 3.3 to 3.5 points (satisfied with $42 \%$ in $2017,50 \%$ in 2019 , not satisfied $-21 \%$ in $2017,19 \%$ in 2019). ${ }^{1}$

The emergence and spread of new forms of social capital are influenced by objective and subjective reasons. As social, economic, technological, political and other external conditions change, which significantly affect the internal state of economic entities, transformational changes in their behavior occur, and these changes lead to changes in relationships and the emergence of new forms of social capital. An example is the formation and accumulation of social capital of united territorial communities. Adoption of the Law of Ukraine "On Voluntary Association of Territorial Communities" (February 5, 2015), approval of the Methodology of formation of capable territorial communities (April 8, 2015), developed by the Ministry of Regional Development, Construction and Housing and Communal Services of Ukraine, as well as Reform of Intergovernmental Budget Relations in the context of decentralization reform, it has provided local communities with current legal conditions and economic incentives to more efficiently fill their budgets, move to selfsufficiency and carefully plan their donations.

These changes have led to a strengthening of the revenue side of local budgets. The most significant result of fiscal decentralization was the increase in the share of local taxes and fees in local

\footnotetext{
${ }^{1}$ A nationwide public opinion poll was conducted by the Kyiv International Institute of Sociology at the request of the Ilko Kucheriv Democratic Initiatives Foundation from 8 to 20 August 2019. The survey was conducted in 103 settlements in all regions of Ukraine except the Autonomous Republic of Crimea. In the Donetsk and Luhansk regions, polls were conducted only in territories controlled by Ukraine. A total of 2040 respondents were interviewed, who by their characteristics represent the adult population of Ukraine (over 18 years). The sampling error does not exceed $2.3 \%$.
} 
budget revenues from $2.5 \%$ in $2012-2014$ to $30 \%$ in 2018 . For the first time in 2018 , local budgets exceeded the state budget and accounted for $52 \%$ of Ukraine's consolidated budget.

Over $15 \%$ of GDP is redistributed through local budgets in Ukraine. The share of own revenues of local budgets (general fund) in GDP in 2018 amounted to 7.1\% (in $2014-5.1 \%$ ), in 2019 it is estimated $6.8 \%$, and the own revenues of local budgets increased from 68.6 billion UAH in 2014 to UAH 234.1 billion. - in 2018, the forecast for 2019 - up to 267 billion UAH. New financial conditions have become an important factor in the dynamic formation of ATGs: as of 2015, 159 were formed in Ukraine; for 2016 - 366; for 2017 - 665; and as of March 2019, there were already 884 United Territorial Communities (CTGs). As of April 2019, the territory of the formed ATGs is more than a third $(38.5 \%)$ of the total area of Ukraine. These communities are home to over 9.1 million people (25.7\% of the total population of Ukraine). In general, nearly $70 \%$ of the population of the population is in the prosperous communities, such as OTGs and regional cities. The average number of territorial communities merged into one CAG is 4.6 , and the average population of one CAG is 10 284 people [6]. Therefore, further successful implementation of local self-government reform leads to a willingness of citizens to act together in order to achieve positive goals and change in their lives.

According to sociological research, the processes of accumulation of social capital have ambiguous trends: the percentage of active Ukrainians is only $15 \%$ to $25 \%$; most Ukrainians do not feel responsible for the situation in their community; NGOs are often encouraged by foreign donors, and these funds are often channeled to the needs of public officials; the interaction of nongovernmental NGOs with the government decreases; there is competition between NGOs instead of constructive cooperation.

At the same time, new forms of interaction of NGOs are gradually emerging through social networks, implementation of joint projects and direct, informal communication of leaders and activists of NGOs. The peculiarity of NGOs is that their social capital is formed around the desire to provide assistance to a specific target audience (participants of the anti-terrorist operation (ATO), veterans, disabled people, children), often with the assistance of the media. This applies to such areas as: medical, psychological and social rehabilitation and adaptation of ATO participants and their families; solving problems of internally displaced persons, adapting them to local communities, providing assistance to socially disadvantaged, low-income groups; activities of advisory and advisory bodies, public councils; implementation of joint projects.

The development of social capital in communities should be facilitated by specially designed programs and projects aimed at stimulating citizens' activity and regulating their participation in solving local issues and shaping and implementing local policies, as well as creating conditions for communication between residents and community associations.

According to the results of special studies, the programs of 8 regions of Ukraine: Volyn, Dnipropetrovsk, Donetsk, Lugansk, Odesa (project), Sumy, Kharkiv, Kherson oblasts and Kyiv are fully provided for the conditions for the formation and development of social capital in communities. The objectives of the programs of 5 regions of Ukraine: Zhytomyr, Transcarpathian, Zaporizhia, Poltava and Rivne do not provide adequate conditions for the formation and development of social capital in communities. IC communities are formed as they participate in solving local problems. Forms of participation differ depending on the tasks: work in the composition of organizing committees, expert and working groups, advisory and advisory bodies at local executive bodies and local self-government bodies; participation in public hearings, holding community meetings, promoting activities of executive bodies, proposing projects and programs, etc. Such forms include public-private partnerships, formation of management mechanisms in ATG, ACMH, in public associations.

The development of social capital at the local level is facilitated by the creation of "digital" communities where the following are important: activity in social networks; launching investment sites for potential investors; clear definition of priorities and strategies for community development, etc. Even in such a framework, new forms of social capital do not automatically emerge. Their formation is influenced by such factors as: the desire of the community to guarantee safety and therefore to preserve the commonality of interests and actions; uncertainty and unpredictability of environmental changes; unequal desire for cohesion among representatives of different social groups, varying in income level, property scale, access to certain resources, etc.

At the enterprise level, social capital also does not automatically emerge. With skillful purposeful management, it develops as a corporate social capital, which can be characterized by such processes and 
phenomena as: improving the image and reputation of the company, attracting new customers, increasing the competitiveness of the company and more. And the management measures aimed at accumulating the social capital of the enterprise should be the ones that will hinder the communication and teaming of employees for making collective decisions; delegation of authority, formation of corporate culture, definition of mission, values, priorities in the development of enterprise development strategy.

Special social institutions (foundations, NGOs, innovation centers, etc.) are innovative in terms of opportunities for forming global social capital, reflecting the perspectives and mechanisms of social policy in different countries (for example, SITRA (Finland) - a non-governmental organization contributions from private corporations and implements five major programs: innovation, health, food and nutrition, environmental protection and machine support; Estonian Development Fund (Argengufond), joint venture supported by innovative projects and venture investments in Estonia; Enterprise Social Investment Fund (UK) supporting a social investment business on behalf of the UK Ministry of Health; Social Innovation Park (Spain) focused on creating new social enterprises with access to training and mentoring (10, p.162).

Conclusions. The accumulation of social capital is one of the regularities of socialization of the modern economy. This process objectively occurs at different levels of economic relations. In order to accelerate the processes of socialization and increase the level of people's trust in the authorities, new forms of interaction of the authorities with civil society, joint actions and socially important actions are needed. Unfortunately, these processes can also generate negative social capital. Expert studies have identified such major trends in the accumulation of social capital in Ukraine as: situational activity and cohesion, which become higher in the face of social cataclysms, and thus have a wavy nature; inefficiency of governmentpublic relations due to a lack of understanding of the mechanisms of effective cooperation and its own benefits, incompetence of NGOs and their leaders. For a long time, the cause of mistrust in Ukrainian society is the existence of the problem of social injustice (especially in the system of distribution of power and property, ownership, disposal, management of objects of property; in the distribution and use of income), which reduces the interest in joint actions, creates controversy between the participants of economic relations, lack of interest in the formation of social capital by the ruling elite, misunderstanding of citizens of the expediency of cooperation and their own benefits from it.

Promising in terms of social capital accumulation in Ukraine, further digitalization processes are envisaged, providing for the creation of new platforms for electronic interaction by 2025: econtracting, e-invoicing, e-docflow, e-business services (LegalTech, FinTech, InsurTech, in particular, using blockchain technologies (smart contracts, etc.), platforms for life support (education, medical, transportation, public safety, environmental monitoring, etc.) Implementation of these areas will improve interaction between business ub'yektamy, citizens, and representatives of the state.

\section{REFERENCES}

1. Coleman J. (1990). Foundations of Social Theory/ J. Coleman. Cambridge MA: Harvard University Press. 1014 p.

2. Glaester E. L. (2001). The Formation of Social Capital. The Contribution of Human and Social Capital to Economic Growth and Well-being: International Symposium Report, Human Resources Government Canada and OECD. Ottawa, P.56-69.

3. Global Crowdfunding Market 2017-2021. Retrieved from: https:/finance.yahoo.com/news/globalcrowdfunding-market-2017-2021-182400851.html

4. Gusak N. (2016). Best experience and current trends in the development of social entrepreneurship: Ukraine (survey results). Kyiv, November 16, 2016

5. Goncharenko N. Social capital: conceptual ambiguity in social and philosophical discourse. Philosophical problems of the humanities. Collection of scientific works. Retrieved from: http://www.infolibrary.com.ua/books-text-11431.html

6. Decentralization of power: agenda for the medium term (2019). Analytical report. Author: Zhalilo Y., Shevchenko O., Romanova V. National Institute for Strategic Studies. Kiev. 115p.

7. Kovalchuk KF, Kozenkova NP (2017). Network methods of financing the activity of innovative enterprises. Economic Bulletin. №4. Pp. 142-153.

8. The official page of "Spilnokosht". Retrieved from: https://biggggidea.com

9. Patnam R. (2001). Playing bowling alone: the decline of America's social capital Independent cultural journal “"̈’. No. 21. Retrieved from: http: //www.ji.lviv ua / n21 texts / putnem.htm;

10. Development of the innovation system of Ukraine in the European scientific and technological space: scientific report / ed. Corresponding Member NAS of Ukraine I. Egorova; NAS of Ukraine, State 
Institution «Institute of Economics and Forecasting of NAS of Ukraine». Kyiv, 2018. 198 p.: Retrieved from: http://ief.org.ua/docs/sr/302.pdf c/ 165-166.

11. Rose R. (2002). Achieving goals in a quasi-modern society: social networks in Russia. Social Sciences and Modernity. № 3. P. 15-23.

12. Social entrepreneurship. Lending to Small Business Clients under the Savings Bank Program and the WNISEF Foundation. Retrieved from: https://www.oschadbank.ua/en/ business / loans / wnisef.pdf

13. Ukrainian freelance market is conquering the world. Retrieved from: https://business.ua/business/ 4442ukrainskyi -rynok-frilansu-zavoiovuie-svit

14. Fukuyama F. (2004). Our posthuman future: the consequences of the biotechnological revolution. Moscow: AST; Suite. 352 p.

15. Shved V., Yablochnikov S. (2018). Features of Sharing Economy in Ukraine. Business. Education. Right. Bulletin of the Volgograd Institute of Business. No. 2 (43), P. 76. 